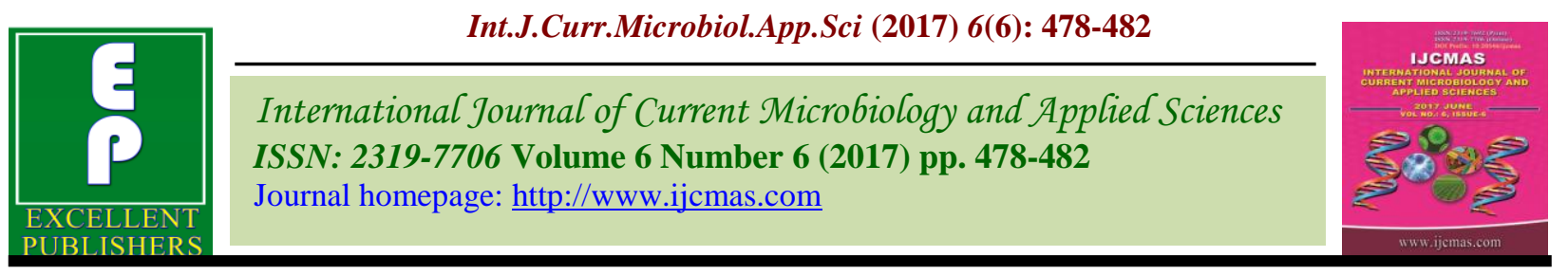

Original Research Article

https://doi.org/10.20546/ijcmas.2017.606.055

\title{
Effect of Pre-Storage Seed Invigoration Treatment in Onion (Allium cepa L., cv. Agrifound Dark Red) for Improved Germinability and Field Performance
}

\author{
Sabyasachi Patra* \\ Crop Research and Seed Multiplication Farm (CRSMF), Tarabag, University of Burdwan, \\ Burdwan-713104, West Bengal, India \\ *Corresponding author
}

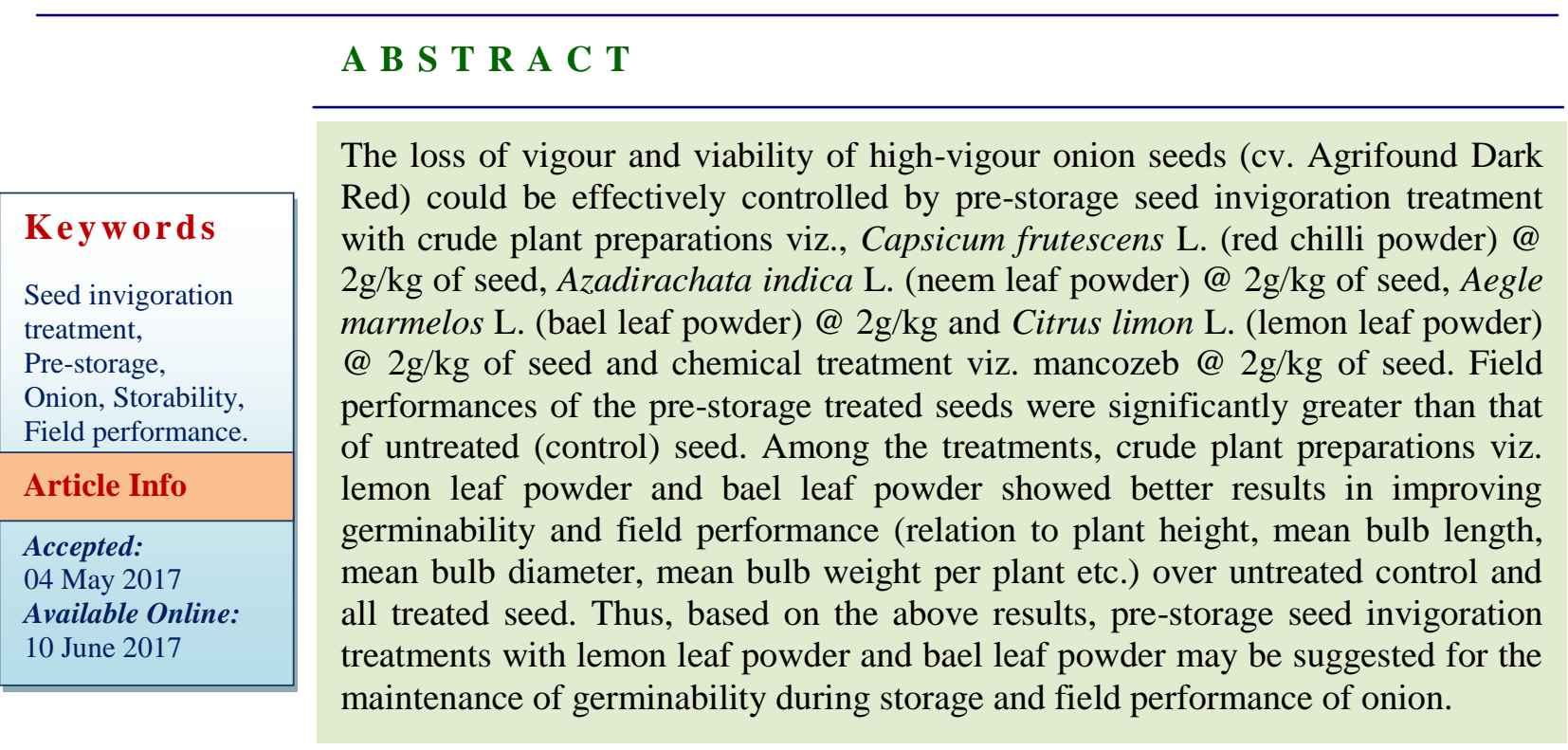

\section{Introduction}

Seed vigour consists of those properties, which conclude the potential for rapid uniform emergence and development of normal seedlings under a wide range of field conditions (ASPB, 2003). The main factors affecting of seed storage capability are the content of high temperature, ambient relative humidity, and seed moisture (Abdul-Baki, 1980). The loss of viability in onion seed is very fast, normally within a year (Singh and Bhonde, 2003). In this matter poses a serious problem to maintain vigour and viability of onion seed for longer periods under ambient condition. To prevent seed deterioration and better field performance Pre-storage dry seed invigoration treatments of stored onion seeds found effective (Sengupta et al., 2005). By reason of the few work had been on onion seed, the present study was conducted at Crop Research and Seed Multiplication Farm, The University of Burdwan to evaluate the effect of various Seed invigoration treatments on germinability and field performance of onion (cv. Agri found Dark Red).

\section{Materials and Methods}

Harvest fresh Seeds of onion: cv. 'Agrifound Dar Red' (500g) were collected during March, 2016 from the local market of 
Burdwan District. After collection, seeds were cleaned and dried in the sun for 5-6 days to a moisture content of $8 \%$ for safe storage. Seeds were then stored in the $500 \mathrm{ml}$ capacity rubber stoppered glass bottles under ambient conditions in the laboratory till seed invigoration treatment.

After cleaning and drying seeds were divided into six lots for Pre-storage seed invigoration treatments. After treatments seeds were stored in $100 \mathrm{ml}$. capacity rubber stoppered glass bottle, each containing $50 \mathrm{~g}$ seeds. Onion seeds were dry-dressed with crude plant material, viz. neem leaf powder (Azadirachta indica L.) at $2 \mathrm{~g} / \mathrm{kg}$ of seed, red chilli powder (Capsicum frutescens L) at $2 \mathrm{~g} / \mathrm{kg}$ of seed, bael leaf powder (Aegle marmelos L.) at 2 $\mathrm{g} / \mathrm{kg}$. of seed, lemon leaf powder (Citrus limon L.) at $2 \mathrm{~g} / \mathrm{kg}$ of seed and chemical viz. mancozeb at $2 \mathrm{~g} / \mathrm{kg}$ of seed in rubber stoppered glass bottles at room temperature $(29.83 \pm 1 \square \mathrm{C})$. After treatment, bottles were shaken twice in a day upto 7 days for thorough mixing of crude plant materials and chemical with the seeds and the bottles were kept in the laboratory under ambient conditions.

After treatment, seeds were subjected to natural ageing under ambient conditions for 180 days to evaluate the treatment effects on germinability. Natural ageing was done by placing the seeds of the different treatments in perforated paper packets kept in cloth bags. The cloth bags containing paper packets were shuffled at regular intervals (7 days) for uniform ageing. Germination tests were carried out following the inclined glass plates blotter method of Punjabi and Basu (1982). Germination tests of the treated and untreated seeds (minimum 400 seeds for each treatment as specified by ISTA (1996) were done immediately after treatment and after natural ageing for 180 days. Data on germination percentage, root and shoot length were recorded after germination for 7 days at $29.83 \pm 1 \square \mathrm{C}$ temperature.

A field experiment was carried out at Crop Research and Seed Multiplication Farm, The University of Burdwan, West Bengal during the period 2016-17 (September to January); using completely randomized block design with three replications for each treatment. After land preparation, the plot was divided into 18 subplots $(6$ treatments $\times 3$ replications); each measuring $10 \mathrm{sq} \mathrm{m}(5 \mathrm{~m} \times$ $2 \mathrm{~m})$. About 10 tonnes of well-rotted FYM was added at the time of land preparation. Nitrogen, phosphorus and potash was applied at $100 \mathrm{~kg}, 60 \mathrm{~kg}$ and $80 \mathrm{~kg} \mathrm{ha}^{-1}$ through urea, 10:26:26, single super phosphate and murate of potash, respectively. Half dose of nitrogen and full dose of phosphorus and potash were applied as basal dose before transplanting and rest half dose of nitrogen was applied in two equal splits at 30 and 60 days after transplanting. At first nursery bed was prepared following the recommended practices and then treated and untreated seeds were sown at the rate of $10 \mathrm{~kg} / \mathrm{ha}$. The cultural practices such as 45 days old seedlings were transplanted by giving a space $15 \mathrm{~cm}$ between the rows and $15 \mathrm{~cm}$ between the plants, first irrigation was given just after transplanting and further irrigations were given at 10-15 days interval during the cropping period. The other cultural practices such as intercultural operations were maintained for good bulb development, hand weeding was done as and when required and pest management practices were followed as usual.

Data on plant height, no. of leaf, length of bulb, diameter of bulb, fresh bulb weight etc. were taken replication-wise after 125-130 days of transplanting for each treatment from ten plants those were randomly selected in each plot and tagged. Data collected on various parameters were statistically analyzed 
(Fisher, 1948) to evaluate the treatment effect on germinability and field performance of onion seed. Vigour index data were calculated as germination percentage multiplied by seedling length.

\section{Results and Discussion}

Germination test conducted immediately after pre-storage treatment, treated seeds did not show any significant beneficial effect on germination percentage root length, shoot length over untreated control (Table 1). But, after natural ageing at room temperature for 180 days, germination percentage, root length and shoot length of treated seeds showed significant improvement over untreated control (Table 1). Among the treatment, lemon leaf powder followed by bael leaf powder showed significant improvement on germ inability. The field performance, especially, plant height $(\mathrm{cm})$, number of leaf per plant, mean bulb length $(\mathrm{cm})$ per plant, mean bulb diameter $(\mathrm{cm})$ per plant, mean bulb weight (g) per plant were significantly improved in treated seeds than the untreated control. Among treated and untreated seed, lemon leaf powder followed by bael leaf powder showed better results in improving field performance (relation to number of leaf per plant, mean bulb length $(\mathrm{cm})$ per plant, mean bulb diameter $(\mathrm{cm})$ per plant, mean bulb weight (g) per plant) (Table 2). But no. of leaf was maximum in lemon leaf powder than untreated (control) and all treated seed.

Extend the duration of seed storage would increase the metabolic activity of the seeds, as result decrease the reserve substance content and reduce the dry material weight of the seeds (Bewley and Black, 1994). The role of natural plant preparations could be due to reduced lipid peroxidation because volatile aldehyde production was lower in seeds treated with such preparations than in the control (Pal and Basu, 1994; Mandal et al., 2000).

Table.1 Effect of pre-storage seed invigoration treatments on the germ inability of onion seed (cv. Agri found Dark Red) immediately after treatment and natural ageing under ambient conditions for 180 days [average (average $78.5 \pm 1.88 \mathrm{RH}$ and $29.83 \pm 1^{\circ} \mathrm{C}$ )]

\begin{tabular}{|l|l|l|l|l|l|l|l|l|}
\hline Before ageing & $\begin{array}{l}\text { Germination } \\
(\%)\end{array}$ & $\begin{array}{l}\text { Mean } \\
\text { root } \\
\text { length } \\
(\mathrm{mm})\end{array}$ & $\begin{array}{l}\text { Mean } \\
\text { shoot } \\
\text { length } \\
(\mathrm{mm})\end{array}$ & $\begin{array}{l}\text { Vigour } \\
\text { Index }\end{array}$ & $\begin{array}{l}\text { Germination } \\
(\%)\end{array}$ & $\begin{array}{l}\text { Mean } \\
\text { root } \\
\text { length } \\
(\mathrm{mm})\end{array}$ & $\begin{array}{l}\text { Mean } \\
\text { shoot } \\
\text { length. } \\
(\mathrm{mm})\end{array}$ & $\begin{array}{l}\text { Vigour } \\
\text { Index }\end{array}$ \\
\hline Control & 80.16 & 51.33 & 87.16 & 11101.35 & 62 & 16.16 & 59.33 & 4680.38 \\
\hline Neem leaf powder & 80 & $49 . .83$ & 96.05 & 11670.4 & 65.5 & 20.66 & 57.16 & 5097.21 \\
\hline Lemon leaf powder & 80.66 & 49.83 & 95 & 11681.98 & 74 & 26.5 & 80.33 & 7905.42 \\
\hline Red chilli powder & 81.16 & 51.16 & 96.76 & 12005.18 & 75 & 18 & 51.5 & 5212.5 \\
\hline Bael leaf powder & 82.5 & 53.5 & 97.11 & 12425.32 & 71.5 & 29.5 & 68.16 & 6982.69 \\
\hline Mancozeb & 80 & 48.5 & 97.08 & 11646.4 & 68.5 & 20.66 & 63.83 & 5787.56 \\
\hline CD (P=0.05) & NS & NS & NS & -- & 2.61 & 1.96 & 3.82 & -- \\
\hline
\end{tabular}

*Treatments were given to one month old seed

*Data on germination percentage, root and shoot lengths were recorded after germination for 7 days at $30 \pm 1^{\circ} \mathrm{C}$.

*Vigour index was calculated by multiplying the germination percentage with seedling length.

N.S. - Non significant 
Table.2 Effect of pre-storage seed invigoration treatments on field performance and productivity of Onion (cv. Agri found Dark Red)

\begin{tabular}{|l|c|c|l|l|c|}
\hline Treatments & $\begin{array}{l}\text { Plant height } \\
(\mathrm{cm})\end{array}$ & No. of leaf/plant & $\begin{array}{l}\text { Mean Bulb } \\
\text { length } \\
(\mathrm{cm}) / \text { plant }\end{array}$ & $\begin{array}{l}\text { Mean Bulb } \\
\text { diameter } \\
(\mathrm{cm}) / \text { plant }\end{array}$ & $\begin{array}{l}\text { Mean Bulb } \\
\text { weight (g)/plant }\end{array}$ \\
\hline Control & 43.33 & 8 & 5.83 & 16 & 48.33 \\
\hline Neem leaf powder & 51 & 13 & 6.16 & 16.13 & 65 \\
\hline Lemon leaf powder & 68.33 & 18 & 7.16 & 17.93 & 101 \\
\hline Red chilli powder & 52 & 13.66 & 6.43 & 17 & 71 \\
\hline Bael leaf powder & 56 & 10.33 & 6.6 & 17.33 & 72.33 \\
\hline Mancozeb & 48.33 & 14.66 & 6.03 & 16.66 & 71.66 \\
\hline CD $(\mathrm{P}=0.05)$ & 11.5 & 4.40 & 0.58 & 2.20 & 4.96 \\
\hline
\end{tabular}

Some physiological and biochemical changes directing to seed deterioration have been related to increased activity of enzymes (catalase. peroxidase, etc.), lipid auto oxidation (Basu and Rudrapal, 1980) and a subsequent events beginning with a chain of biochemical events, predominantly membrane damage and weakened of biosynthetic reactions, and then arising losses of various seed performance attributes, beginning with reduced germination rate, reduced field emergence, increased numbers of abnormal seedlings and finally seed death. The loss of viability results in irreversible chemical and structural changes to cellular constituents (Walters et al., 2010).

Therefore, pre-storage seed invigoration treatments in high vigour onion seeds with crude plant materials, viz. lemon leaf powder (Azadirachta indica L. @ 2g/kg), bael leaf powder (Aegle marmelos L. @) 2g/kg) of seed respectively are recommended for the improvement of germinability and field performance.

In conclusion, seed invigoration treatment has become popular among horticultural practitioners to improve germinability as well as field performance of onion seed treated with pre storage seed invigoration treatments in high vigour onion seeds with lemon leaf powder (Citrus limon L) @ $2 \mathrm{~g} / \mathrm{kg}$ ) and bael leaf powder (Aegle marmelos L) @ 2g/kg of seed respectively.

\section{References}

Abdul-Baki, A.A., 1980. Biochemical aspects of seed vigour. Hort. Sci., 15: 765-71

ASPB, 2003. Regulations on the Sale of Planting Seed in Arkansas. Arkansas state plant board, Box 1069, Little Rock, Arkansas-72203

Basu, R.N. and Rudrapal, A.B., 1980, Iodination of mustard seed for the maintenance of vigour and viability. Indian J. Exp. Biol., 18: 492-494.

Bewley, J.D. and M. Black, 1994. Seeds: physiology of development and germination. Plenum Press, New York, p. 445

Fisher, R.A. 1948. Statistical methods for research workers. Oliver and Bboyd. Edinburhg.

International Seed Testing Association. 1996. International Rules for Seed Testing: Rules 1996. Seed Sci. and Technol. 24: Supplement 21996.

Mandal, A.K., De, B.K., Saha, R. and Basu, R.N.(2000). Seed invigoration treatments for improved storability, field emergence and productivity of 
soybean (Glycine $\max$ [L.] Merrill). Seed Sci. and Technol., 28: 201-207.

Pal, P. and Basu, R.N. (1994). Extension of wheat seed viability with plant leaf powders and an aspirin containing pharmaceutical preparation. Indian Agric., 38: 145-149.

Punjabi, B. and Basu, R.N. (1982). Testing germination and seedling growth by an inclined glass plate blotter method. Indian J. of Pl. Physiol., 25: 289-295.

Sengupta, A.K., De, B.K. and Mandal, A.K. 2005. Pre-storage seed invigoration treatments for the maintenance of vigour, viability and field performance of high-vigour onion seed (Allium cepa L.). Seed Sci. Technol., 33; 753-760.

Singh, D.K. and Bhonde, S.R. 2003. Studies on the efficacy of certain growth regulators on seed viability and vigour in onion. NHRDF Newsletter xxiii (1) 10-16.

Walters C, Ballesteros D and Vertucci V A (2010), "Structural mechanics of seed deterioration: Standing the test of time", Plant Science, Vol. 179, pp. 565-573.

\section{How to cite this article:}

Sabyasachi Patra. 2017. Effect of Pre-Storage Seed Invigoration Treatment in Onion (Allium сера L., cv. Agrifound Dark Red) for Improved Germinability and Field Performance. Int.J.Curr.Microbiol.App.Sci. 6(6): 478-482. doi: https://doi.org/10.20546/ijcmas.2017.606.055 